ZalǫcZnilf

DOI 10.21697/zk.2020.7.06
Uznanie autorstwa-Użycie niekomercyjne-Bez utworów zależnych
Zatącznik Kulturoznawczy 7/2020

TEMAT NUMERU 1: HITCHCOCK - ROZCHYLANIE KURTYNY (W 40. ROCZNICE ŚMIERCI REŻYSERA)

\title{
ANALIZA GRAFICZNEJ ZASADY \\ KONTRASTU W ZAWROCIE GŁOWY ALFREDA HITCHCOCKA
}

AgniesZKa SMAGa

Wydział Nauk Humanistycznych UKSW
Department of Humanities,
Cardinal Stefan Wyszyński University in Warsaw
a.smaga@uksw.edu.pl
ORCID: 0000-0003-2722-4592

ORCID: 0000-0003-2722-4592

\section{TECHNIKA, RYSUNEK, MALARSTWO - DROGA HITCHCOCKA DO FASCYNACJI GRAFICZNYCH}

Termin "grafika” - zgodnie z jego znaczeniem etymologicznym - rozumiany jest jako: (1) artefakt techniczny, (2) czynność wykonywaną przy użyciu sprzętu designerskiego, (3) wizualny ślad po narzędziu. Grafika - w odróżnieniu od innych mechanizmów rejestracji danych, np. pisma, rysunku, malarstwa - wymaga bardzo skomplikowanych narzędzi i materiałów, podłoży i sprzętów drukujących. Dlatego tak silnie integrowała się i nadal integruje z naukami i odkryciami technicznymi. Symbioza ta skutkuje powstaniem (1) nowych sprzętów graficznych, które wprowadzają (2) innowacyjne procedury wytwarzania (3) różnosemiotycznych znaków kulturowych. Artefakty techniczne i ich procedury operacyjne pozwalają twórcy na kreowanie nowych graficznych efektów wizualnych związanych np. z integracją słowa i obrazu, zmiennymi punktami widzenia, śmiałymi kadrami i montażami, kontrastowymi zestawieniami barwnymi itd.

Sugerowana w tytule artykułu zależność filmu od grafiki wydaje się oczywista dopiero w kontekście mediów cyfrowych. Funkcjonuje ona tam już na poziomie ontologii obrazu dźwiękowo-kinetycznego i ma swe konsekwencje w zakresie techniki generującej i wyświetlającej ikon digitalny. Graficzny punkt - piksel - stanowi bowiem substancjalny, operacyjny i wyświetlany 
komponent obrazu rejestrowanego przy udziale cyfrowej kamery filmowej'. Już $\mathrm{w}$ procesie produkcji, a przede wszystkim $\mathrm{w}$ postprodukcji, procesy graficzne dosłownie „królują”. Za ich pośrednictwem dokonywane są operacje na kolorze, światłocieniu, perspektywie, kadrze, ujęciu. Używane są narzędzia typu warstwy, montaże, filtry, selekcje, efekty specjalne i inne. $\mathrm{Z}$ pewnością to $\mathrm{m}$.in. techniki, procedury i zasady graficzne, np. kontrast, budują specyfikę filmów produkowanych i postprodukowanych przy udziale domeny cyfrowej ${ }^{2}$.

Okazuje się, że analogiczne zjawisko można zaobserwować już w przypadku filmów nakręconych kamerą $35 \mathrm{~mm}$ przy udziale negatywu, najpierw naświetlanego, potem wywoływanego chemicznie i wykonywanego na taśmach. Przykłady takich efektów graficznych odnaleźć można m.in. w twórczości kinematograficznej Alfreda Hitchcocka, który znany był z umiłowania etapu montażu, czyli właśnie procesu postprodukcji. Dokonywał on bardzo starannej i drobiazgowej obróbki końcowej filmu, dopiero wtedy nadawał scenom właściwy kontrast, kadr i tempo. Zatem Hitchcockowski suspens budowany był z poziomu produkcji, a przede wszystkim graficznej postprodukcji - za pośrednictwem m.in. edycji montażowej3. W tym przypadku droga do designerskich proweniencji filmu wiodła przez zainteresowania i edukację w zakresie techniki, rysunku i malarstwa.

Hitchcock, poszukując swojej ścieżki zawodowej, najpierw uczył się w szkole inżynierskiej (w London County Council School of Engineering and Navigation). Najprawdopodobniej uzyskane wykształcenie techniczno-praktyczne spowodowało, że reżyser przyjmował często pozycję

1 Graficzne notacje poprzedzają nawet same rozwiązania algorytmiczne i budowę wewnętrznych oprogramowań cyfrowych kamer filmowych.

2 Sytuacja ta dotyczy przede wszystkim filmów nagrywanych bezpośrednio przy udziale kamery cyfrowej, tylko częściowo tych tworzonych za pośrednictwem kamery tradycyjnej, następnie skanowanych przy udziale urządzeń graficznych. Można nawet pokusić się o postawienie śmiałej tezy badawczej, że wszystkie formy kulturowe, również film, generowane bezpośrednio w środowisku cyfrowym, stają się pewną odmianą grafiki. Wtedy mielibyśmy do czynienia ze zjawiskiem odwrotnym niż w przypadku sugerowanym w tytule artykułu. Analizowany byłby wpływ komponentów dźwiękowych i kinetycznych na grafikę cyfrową.

3 Por. P. Ackroyd, Alfred Hitchcock, tłum. J. Łoziński, Poznań 2015, s. 243-244. 
człowieka biegłego w zagadnieniach sztuki filmowej, analogicznie zresztą do grafika - obeznanego w różnorodnych technikach graficznych. W kwestiach technologicznych wspierała go również żona Alma ${ }^{4}$ W przeprowadzonej wiele lat po za końćzeniu edukacji rozmowie z zaprzyjaźnionym francuskim reżyserem François Truffautem Hitchcock mówił nawet: „[...] nie interesuje mnie morał czy przesłanie filmu: Można by powiedzieć, że jestem jak artysta, malujący kwiaty lub ten stół. Interesuje mnie tylko sposób ujmowania przedmiotów" . Fascynacje techniczne skutkowały wprowadzeniem wielu innowacji wizualnych i efektów specjalnych.

Hitchcock wielokrotnie eksperymentował również w zakresie pracy kamery filmowej. Od momentu projekcji filmu Lokator (The Lodger - A story of the London Fog, 1927) funkcjonuje nawet określenie „Hitchcock Picture”, rozumiane właśnie jako specyficzne dla tego reżysera efekty wizualne ${ }^{6}$. Zawrót głowy (Vertigo, 1958) jest doskonałym przykładem wykorzystania tychże gier graficznych. Dla oddania tytułowej dolegliwości chorobowej akrofobii, która polega na złudzeniu ruchu kołowego otoczenia lub własnego ciała - Hitchcock wprowadził animowaną formę spiralną. Ten element, należący do ulubionych motywów reżysera, zaprojektowany został przez Saula Bassa, a wykonany przez Johna Whitneya, który wykreślił spiralne formy za pomocą urządzenia pierwotnie służącego do poruszania działami przeciwlotniczymi, które to urządzenie on sam nazywał „komputerem”"

${ }^{4}$ Peter Ackroyd, powołując się na liczne wypowiedzi współpracowników reżysera, pisał: „Hitchcock jak zawsze zajmował się trudnościami technicznymi, przed którymi stawał, oraz wizualną stroną przedstawianej na scenie opowieści"; ibidem, s. 240.

5 F. Truffaut, Hitchcock/Truffaut, współpraca H. Scott, tłum., oprac. i posł. T. Lubelski, Izabelin 2005, s. 50.

6 Ibidem, s. 44.

7 Designer odwoływał się do matematycznych koncepcji Jules’a Antoine’a Lissajousa (zob. M. Ples, Krzywe Lissajous - piękno drgań, „Młody Technik” 2015, nr 6, s. 76-77). Natomiast Whitney, traktowany jako pionier animacji komputerowej, został zatrudniony do przełożenia tych skomplikowanych, dwuwymiarowych projektów Bassa w ruchome, trójwymiarowe obrazy; zob. T. McCormack, Did 'Vertigo' Introduce Computer Graphics to Cinema?, 9.05.2013, Rhizome, https://rhizome.org/editorial/2013/may/9/did-vertigo-introduce-computer-graphics-cinema/ [dostęp 10.02.2020]. 
Reżyser zastosował również efekt nazywany „vertigo zoom” („Hitchcock zoom") ${ }^{8}$. Stworzył złudzenie optyczne, za pośrednictwem którego widzimy oczami bohatera wydłużającą się spiralę schodów. Efekt powstawał poprzez wydłużenie ogniskowej obiektywu (przybliżanie obrazu zoomem) z jednoczesnym oddaleniem kamery od filmowanego obiektu lub odwrotnie. Do innych ciekawych zabiegów technicznych można zaliczyć obrót kamery o trzysta sześćdziesiąt stopni. W tym przypadku kolisty ruch kamery eksponował użytą w filmie formę spirali.

Hitchcock, obok umiejętności stricte technicznych, wykazywał również dużą dbałość o szczegóły. Fascynację tę najprawdopodobniej zapoczątkowały zajęcia w zakresie nauk ścisłych i lekcje rysunku technicznego ${ }^{9}$. Podobnie jak w przypadku uwarunkowań technicznych, także tu wzajemne powinowactwa rysunku i grafiki są bardzo ścisłe i dotyczą zarówno samej czynności, jak i śladu po narzędziu. W technikach warsztatowych rysunek poprzedza rycinę - odbitkę graficzną; nanoszony jest na podłoże, potem ryty lub trawiony - zależnie od wybranej techniki graficznej. W grafice projektowej czynność rysowania wykorzystywana jest do szybkiej konceptualizacji pomysłu. Rysunek z grafiką łączy wreszcie sam środek wyrazu artystycznego: linia. Grafik Richard Poulin pisze: „[...] człowiek stworzył linię jako najprostszy środek komunikacji"10, dokonywanej za pośrednictwem obrazu i pisma. Zatem w przedstawieniu graficznym linia, po pierwsze, wiąże tekst z obrazem, po drugie - traktowana jest jako element sticte informacyjny. Definiuje ona kontury i kształty przedmiotów, wyznacza kierunki i podziały, sugeruje porządki, konstruuje wzory i ornamenty, buduje wrażenie ruchu.

8 Inne określenia: dolly zoom, back zoom travelling. Powstałe wrażenia „wciągającej” głębi i ruchu pozornego, który uzyskany jest za pośrednictwem rozwibrowania pola widzenia, przypominają osiągnięcia op-artu i sztuki kinetycznej.

9 Jedna z aktorek drugoplanowych Psychozy miała nawet powiedzieć: „Każdą scenę traktował tak, jakby ją miał rozrysowaną na rysunku technicznym. Kiedyś powiedział mi: »Jeśli odchyli się pani w którąkolwiek ze stron o cal, zburzy to proporcje światła i cienia«. Mógł na przykład powiedzieć: »Dotarłszy do tej linii, patrzy pani pod nogi, oczekuje chwileczkę, a potem znowu spogląda na niego i tak trzyma«"; P. Ackroyd, op. cit., s. 242.

10 R. Poulin, Język projektowania graficznego. Ilustrowany podręcznik podstawowych zasad projektowania graficznego, Warszawa 2011, s. 24. 
Hitchcock, ucząc się rysunku technicznego, kreślił schematy działania maszyn oraz przepływów natężenia prądu i projektował nowe rozwiązania techniczne. Wykonywane czynności rysunkowe przyniosły dwa kluczowe efekty. Z jednej strony pojawiało się zainteresowanie szczegółem i precyzja w oddaniu detali, z drugiej - praktyki rysunkowe umożliwiały „szybkie” wizualne notowanie pomysłów ${ }^{11}$ czy storyboardów do filmów. Zatem linia mogła albo oddawać realistycznie szczegół, albo planować rozwiązanie (nawet fantastyczne), albo łączyć oba sposoby i prezentować z dużym pietyzmem irrealne światy. Obie zależności, z pozoru wykluczające się, wyprowadzone zostały z jednej manualnej zręczności - rysowania. Dlatego Zawrót głowy uznany został za labirynt realistycznych szczegółów, a zarazem za film nierzeczywisty, mało wiarygodny, nawet nonsensowny.

Zainteresowanie linią przerodziło się w jej umiłowanie. Hitchcock najpierw sam został ilustratorem. Potem, gdy przestał już rysować i zajął się filmem, swoich bohaterów czynił rysownikami (np. Midge Wood z Zawrotu głowy). Zawsze zatrudniał artystów, którzy wykonywali storyboardy poprzedzające właściwe filmy ${ }^{12}$. Były wśród nich legendy, m.in. wspomniany wyżej Saul Bass ${ }^{13}$ czy Harold Michelson. Dla Hitchcocka rysunek storyboardowy był przede wszystkim podstawowym narzędziem doprecyzowania własnej wizji twórczej (il. 1 i 2), pojawiał się więc w odmianie projektowej, opisanej wyżej. Dopiero w drugiej kolejności służył on do komunikowania

${ }^{11}$ Midge Wood - bohaterka filmu Zawrót głowy - projektuje nowy typ biustonosza, który „funkcjonuje” na zasadzie mostu wspornikowego, wynalezionego przez inżyniera lotnictwa. W przywołanej dygresji filmowej kolejny raz ujawnia się wzajemna wspólnota myślenia w porządku technicznym i w porządku designerskim.

12 Por. G. Todd, Drawings for a Master: Storyboards From The Films of Alfred Hitchcock, 25.11.2015, Film School Rejects, https://filmschoolrejects.com/gallery-drawings-for-a-master-storyboards-from-the-films-of-alfred-hitchcock-c0bc20e77c03/ [dostęp 10.02.2020].

13 Grafik bardzo szczegółowo rozrysował np. słynną scenę pod prysznicem, obecną w Psychozie. A porównanie jego scenorysów i kadrów filmowych powoduje, że badacze ciągle zastanawiają się nad tym, kto był autentycznym twórcą tej wizualnej sceny (zob. Who Directed the Shower Scene in PSYCHO? [wideo], https:// vimeo.com/86791716 [dostęp 1.02.2010]). 
się ze współpracownikami podczas produkcji. Zamysł filmu, dzięki dokładnie rozrysowanej fabule, był już ukończony, zanim jeszcze ktokolwiek - czy to operator, czy montażysta - zaczął pracę nad ekranizacją. Hitchcock miał „gotowy film”, znał każde ujęcie jeszcze przez rozpoczęciem produkcji. Jego fascynacja filmem często kończyła się na poziomie rozrysowania projektu. Najciekawszy okazywał się moment doprecyzowania w szczegółach wizji twórczej ${ }^{14}$.
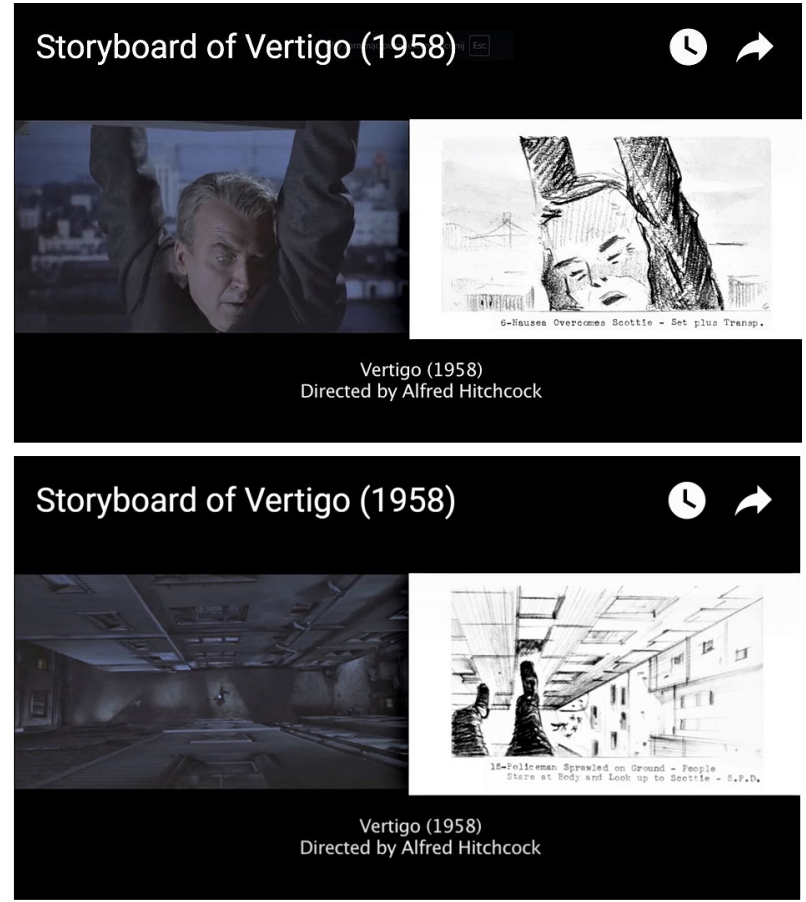

Il. 1 i 2. Porównanie kadru i scenorysu w Zawrocie głowy (1958)

Najprawdopodobniej to doświadczenie techniczne i rysunkowe pozwoliło Hitchcockowi otworzyć się na zagadnienie obrazowości. Dlatego film był dla

14 Dlatego na planie reżyser sporadycznie „zerkał operatorowi przez ramię”. Mógł w pełni skupić się na grze aktorów, którym jednak nie pozostawiał wiele miejsca na ich własną ekspresję. Szczegóły gry aktorskiej miał również zaprojektowane w myślach. 
niego zdarzeniem czysto wizualnym, a sugerowane wyżej pozorne dychotomie - precyzja i fantazja, realizm i irrealizm - „zbudowały” podświadome kontrastowe milieu ikoniczne artysty, wpłynęły na późniejszą stylistykę jego realizacji filmowych ${ }^{15}$, w których dominowały ekspresjonistyczne kontrasty światłocieniowe i barwne. Reżyser po latach powiedział: „Film to mowa obrazów, jestem człowiekiem myślącym kategoriami optyki”16. Można dodać również - złudzeń wzrokowych, jak wykaże dalsza analiza.

Hitchcock jako rysownik operował przede wszystkim przestrzenią pozytywową (czarną linią) i przestrzenią negatywową (białą), które jako środki wyrazu okazywały się niewystarczające do budowania sugestywnych, poruszających wizji. Brakowało mu plam barwnych, przy udziale których mógłby konstruować przedstawienie pełne napięcia i fantazji. Dlatego - m.in. za pośrednictwem rysunku - zainteresował się zagadnieniami stricte artystycznymi ${ }^{17}$. W latach 20, pracując już jako doradca techniczny w zakresie wielkości i przewodnictwa kabli elektrycznych w firmie W.T. Henley's Telegraph Works Company Limited, zapisał się na wydział sztuk pięknych w Goldsmiths' College. Zafascynowany m.in. zagadnieniem kontrastów barwnych, uczył się najprawdopodobniej na kierunku malarstwa, ale miał również zajęcia z grafiki i kompozycji. W wielu wywiadach podkreślał, że wychodził regularnie do galerii i w plener, by szkicować18 ludzi i budynki (ciekawe, że nie malować!). Wtedy zaczął dostrzegać kluczowe zagadnienia sztuki: kompozycję, kolor, cień i światło, głębię ostrości, różnorodne kontrasty obrazowe. Przyznał po latach: „Jedna z pierwszych rzeczy, jakich

15 To umiłowanie opozycji formalnych i w efekcie skrajnych postaw moralnych sięga swymi korzeniami również do chrześcijańskiego wychowania reżysera, które odcisnęło tak istotny ślad na jego osobowości i twórczości. Hitchcock był nawet nazywany człowiekiem „zbudowanym z kontrastów”: psychicznych, egzystencjalnych, poznawczych itd.; F. Truffaut, op. cit., s. 169; por. tytuł książki P. McGilligan, Alfred Hitchcock. Życie w ciemności i pełnym świetle, tłum. J. Matys [et al.], Warszawa 2005.

16 Cyt. za: J. Skwara, Hitchcock, Warszawa 1974, s. 103.

${ }_{17}$ Por. The Hitchcock Zone, https://the.hitchcock.zone/welcome/ [dostęp 10.02.2010].

18 Wśród wykładowców był E.J. Sullivan, rysownik znany z zamiłowania do szczegółu. 
nauczyłem się w szkole plastycznej, brzmiała: nie ma czegoś takiego jak linia"19. Zdecydowana większość przedmiotów nie posiada linii konturowych, a widziany przez nas obrys wyznaczony jest przez kontrastujące ze sobą różnotonalne lub różnobarwne powierzchnie. To one tworzą granice przedmiotów, oddzielając je od tła. Okazuje się, że z punktu widzenia obserwatora jednolite płaszczyzny są mało interesujące. Oczy nastawione są na wyszukiwanie miejsc najbardziej kontrastowych, ponieważ to one dają szanse na rozpoznanie konturów, a na ich podstawie kształtów przedmiotów i - dalej - odczytanie znaków oraz zbudowanie semantyki przedstawienia ${ }^{20}$. Linia konturowa, która buduje zarówno teksty, jak i obrazy, okazuje się najbardziej skutecznym środkiem przekazywania informacji.

W przyrodzie nie ma jednak linii, są tylko światła i cienie. Relacje te budują rodzaj gry, prowadzonej między rzeczywistym przedmiotem (zobaczonym przy udziale fali świetlnej) a jego iluzją (cień przedmiotu jest ową iluzją), czyli między realnością a irrealnością. Sugerowana gra jest już udziałem rysunku, za pośrednictwem którego wprowadzane są ostre kontrasty światłocieniowe między przestrzenią czarną i białą. Dysonanse światłocieniowe i dodatkowo barwne dominują przede wszystkim w malarstwie, stają się również filmowym środkiem wyrazu. Hitchcock poświęcił bardzo wiele uwagi problemowi światłocienia, a młodym operatorom kazał się uczyć malarskiej gry światła od Jana Vermeera van Delft i Rembrandta ${ }^{21}$.

Zależności świetlne okazywały się na tyle fascynujące, że np. Midge mówi o powrocie do swojej „pierwszej miłości”, czyli malarstwa; rysunek

19 Cyt. za: P. Ackroyd, op. cit., s. 24.

20 Efekt ten buduje iluzja wzrokowa, definiowana jako wstęga Macha. Złudzenie to polega na percepcyjnym podnoszeniu kontrastu wzrokowego (wzmacnianiu konturów oglądanych rzeczy) między leżącymi obok siebie płaszczyznami o różnej jasności. Narysowanie konturu zwalnia system wzrokowy z podbijania kontrastu przez mechanizm hamowania bocznego. Kontur jest bowiem rzutowanym na płaszczyznę obrazu wynikiem działania tego mechanizmu. Zob. P. Francuz, Imagia. W kierunku neurokognitywnej teorii obrazu, Lublin 2013, s. 50-73.

${ }^{21}$ Zauważył, że w przyrodzie nie ma linii, również „jak wiadomo kolor w zasadzie nie istnieje, w zasadzie nie ma twarzy, dopóki nie obejmie jej światło"; F. Truffaut, op. cit., s. 168. 
pozwalał jej tylko „zarobić na życie”22. Madeleine (literacki pierwowzór Madeleine/Judy) również maluje, a Flavières (pierwowzór Scottie'go) chciał zostać malarzem. Twierdził jednak, że w zamierzeniach przeszkodził mu brak umiejętności rysunkowych, na co Madeleine odpowiedziała z przekonaniem: „Jakie to ma znaczenie? Przecież tylko kolor się liczy”"23. Malarstwo to operowanie plamami barwnymi, nie linią. Kolory to nasze marzenia. Brak umiejętności widzenia kolorów nazwany zostaje ślepotą, która towarzyszy zwykłej, szarej, „rysunkowej” egzystencji. Barwne marzenia-sny są o wiele piękniejsze niż wszystko, co definiowane jest jako rzeczywistość. Madeleine mówi dalej: „Niech pan sobie wyobrazi, jeśli pan potrafi, kolory, które się dotykają, które zjadają, które się wypijają, które nas przenikają na wskroś. Stajemy się podobni do owadów zlewających się z liściem, jeśli na liściu siedzą, do ryb wśród korali, zmieniających się w korale"24. Powyższy fragment pochodzi z książki Sueurs froides (D’entre les morts), która stała się podstawą filmu Zawrót głowy. Przywołane cytaty okazały się również inspiracją dla rozwiązań barwnych zaproponowanych w produkcji kinematograficznej. Hitchcock przyznał bowiem, że robił ten film, aby zaprezentować przenikniętą marzeniem ludzką naturę. Nie skorzystał jednak z rozwiązań stricte malarskich, czyli płynnych przejść ciągłobarwnych ${ }^{25}$. Zgodnie ze wskazanym wyżej wnioskiem takie rozwiązanie jest mniej „ciekawe i intrygujące” dla ludzkiego oka niż nieciągłe kontrasty barwne. Dlatego reżyser nałożył na kadry filmowe filtry w barwach dopełniających, które wprowadzały fascynujące kontrasty. Skorzystał również z syntetycznych form: spirali, owalu,

22 Namalowała obraz, który stał się kompilacją istniejącego przedstawienia i autoportretu. Propozycja ta nie spotka się jednak z aprobatą Fergusona, gra graficzna przy udziale malarstwa nie powiodła się.

23 P. Boileau, T. Narcejac, Zawrót głowy, tłum. F. Welczer, Czytelnik, Warszawa 1968, s. 71. Tytuł w oryginale brzmiał Sueurs froides (D'entre les morts), co w dosłownym tłumaczeniu znaczyłoby: „Zimne poty (z martwych)”.

24 Ibidem, s. 71-72.

25 Ackroyd zauważy, że „Hitchcock i Buchan mieli podobną wrażliwość: obaj porównywali dreszczowce do baśni, w której atmosfera fantazji i spełnienia marzeń splata się z opowieścią o dobru i złu”; P. Ackroyd, op. cit., s. 80. 
koła. Zastosowane kontrasty - barwne ${ }^{26}$, wielkości, kształtu, przestrzeni oraz graficzne formy bardzo sugestywnie oddawały opozycje realności i irrealności. Film Zawrót głowy skrytykowany został nawet za uderzające użycie kolorów i oceniony jako zbyt kontrastowy barwnie i w skali.

I to właśnie, jak piszą biografowie, dzięki zainteresowaniom i talentowi plastycznemu około 1918 roku Hitchcock został przeniesiony z działu sprzedaży ${ }^{27}$ do działu reklamy. Tutaj uczył się projektowania rysunków reklamowych oraz układania do nich tekstów. Tworzył ogłoszenia i broszury promujące produkty Hanleya. Stworzył i redagował gazetę dla pracowników firmy. Był na bieżąco w sprawach designerskich, zasubskrybował m.in. „Graphis”, wiodący magazyn poświęcony projektowaniu graficznemu. W czasopiśmie tym prezentowane były prace Saula Bassa, którego potem Hitchcock zaangażował do filmu Zawrót głowy.

Praktyka graficzna, podobnie jak wcześniej techniczna, rysunkowa i malarska, zbliżyła reżysera do kina. Wykorzystując zdobyte doświadczenie designerskie, otrzymał pracę w Famous Players-Lasky. Na potrzeby filmów niemych wykonywał napisy na planszach tekstowych, m.in. do realizacji Niebezpieczne kłamstwo (Dangerous Lies, reż. Paul Powell, 1921) czy Appearances (reż. Donald Crisp, 1921), dla wytwórni Paramount Pictures. Plansze zastępowały dialogi lub objaśniały fabułę i miały własną specyfikę, podyktowaną erą ówczesnych filmów: tło było czarne, napisy - białe. Hitchcock tworzył również rysunki, które ilustrowały teksty. Przyszły reżyser - już jako grafik - wykorzystywał wszystkie korelacje obrazu i tekstu, które były dostępne dzięki technice. Zależności te, uzupełnione wkrótce o komponenty dźwiękowe i kinetyczne, zbudowały stylistykę filmów Hitchcocka. Słowo mówione, podobnie jak pisane, było stosowane z dużą ostrożnością, tylko w niezbędnych ujęciach filmowych. Dominującym komponentem stał się bowiem obraz - najpierw czarno-biały, potem barwny ${ }^{28}$. Zdaniem Petera

26 Reżyser miał bardzo dobre wyczucie koloru, porównywany był nawet do nabisty Jeana-Édouarda Vuillarda i kolorysty Pierre’a Bonnarda.

27 Tutaj pracował jako projektant i kreślarz, uczył się planowania i robienia notatek. „Ta praca wykształciła go technicznie, artystycznie i handlowo”; P. McGilligan, op. cit., s. 42.

28 Hitchcock miał wyznać: „»To od Murnaua nauczyłem się opowiadać historię bez słów«. Od tego niemieckiego ekspresjonisty mógł również przejąć: kontrastowy 
Ackroyda „Zawrót głowy został właściwe pomyślany jako film niemy, gdyż oparto go na niezwykle sugestywnych obrazach, jednocześnie i sztucznych, i znakomitych" 29 .

\section{ANALIZA ZJAWISKA KONTRASTU (OBRAZOWEGO, KOMUNIKACYJNEGO, POZNAWCZEGO)}

Zarysowane wyżej relacje słowno-obrazowe z poziomu komunikacyjnego najczęściej wprowadzają zjawisko dysonansu. Reguła kontrastu mówi, że jeżeli dwa obiekty nie są dokładnie takie same, należy wyraźnie zaznaczyć różnicę między nimi. Tekst operuje znakami graficznymi: jednostkami abstrakcyjnymi, nieumotywowanymi, które najczęściej zapisujemy w jednowymiarowej linii wiersza. W ten sposób pismo „odrywa się” od rzeczywistości, do której się odwołuje. Obraz dysponuje natomiast jednostkami ciągłotonalnymi i ciągłobarwnymi. Przy ich udziale tworzy się dwuwymiarowe powierzchnie, które są umotywowane dwoma rozpiętościami rzeczywistości realnej. Trzeci wymiar - obrazowy - budowany jest, podobnie jak w przypadku percepcji, przez zjawisko iluzji głębi. Kontrast nadawczy skutkuje opozycjami odbiorczymi: tekst jest widziany i czytany w linii, obraz - oglądany w układzie zmiennie konstelacyjnym. Pierwszy przede wszystkim buduje abstrakcyjne pojęcia, na podstawie których tworzone są znaczenia, drugi - konkretne przedstawienia.

Ten mocno uproszczony model komunikacyjny byłby nie do przyjęcia przez grafika-projektanta, jak również samego Hitchcocka. Designer zorientowany technicznie i eksperymentalnie - poszukuje mechanizmów sprzętowych i środków wyrazu, które pozwoliłyby silniej zintegrować wskazane porządki komunikacyjne. Dlatego wprowadza on bardziej różnorodne relacje słowno-obrazowe: odmienności i podobieństwa, zależności,

sposób komponowania kadru (za pośrednictwem techniki ruchomej kamery), obrazowość typu wyobraźniowego, abstrakcyjnego (nie ilustracyjnego), emocjonalność i niepewność przedstawienia filmowego. W pierwszym przypadku zauważył, że dla pokazania np. katedry nie trzeba robić jej kopi, wystarczy reprezentatywny, wyeksponowany wizualnie, jej fragment, np. kolumna, a resztę dopowie wyobraźnia. »Liczy się nie to, co widzisz na planie - powtarzał Murnau - lecz to, co widać na ekranie«"; P. Ackroyd, op. cit., s. 35.

29 Ibidem, s. 227. 
współzależności, tożsamości itd. W ostatnim przypadku kontrast kodów komunikacyjnych nawet zanika. Sugerowane relacje słowno-obrazowe można najlepiej prześledzić na podstawie sekwencji tytułowych filmów Hitchcocka.

Tytuł filmu Vertigo pojawia się w formie małego, ledwo zauważalnego, centralnie usytuowanego bliku na oku (il. 3). Blik ten jest odbiciem źródła światła, które - jak powiedzieliśmy wyżej - buduje relacje między realnością a iluzją realności. Dlatego najprawdopodobniej ów napis szybko rozrasta się, by w efekcie zdominować cały wizualny kadr (il. 4). Gra poznawcza, która jest udziałem naszej percepcji, staje się podstawą rozwiązania obrazowego. Kinetyczny element typograficzny posiada tylko linię konturową (w kolorze realnego bliku), brak mu wypełnienia. W ten sposób pozwala on „przebijać” przedstawieniu oka i współgra z komponentami obrazowymi. Natomiast obraz, przefiltrowany przez barwę czerwoną, gubi swe zniuansowane światłocienie ${ }^{30}$. Dlatego nie następuje w tym przypadku ostry podział ról komunikacyjnych na komponenty - znaczące (teksty) i przedstawiające (obrazy). Nie działają one na prawach kontrastu komunikacyjnego, przeciwnie: oba kody wzajemnie się dopełniają i umożliwiają oglądającemu równoczesne ich i przeczytanie, i obejrzenie. Różnosemiotyczne porządki komunikacyjne „działają w linii graficznej” wyznaczonej przez kontur słowa i obrys oka. Linia ta nie jest jednak ustawiona w wierszu, ale na powierzchni obrazowej, różnokonstelacyjnej. W ten sposób zostaje spotęgowany jednoznaczny, ale wielokierunkowy odbiór. W kolejnym kadrze w miejsce tekstu pojawia się komponent graficzny - spirala (il. 5). Przywołana forma powtarza swym kształtem obrys oka i - podobnie jak tekst - rozrasta się w każdym kierunku. Można przypuszczać, że gdyby znana była Hitchcockowi cyfrowa funkcja „zamiany tekstu na krzywe” (efekt graficzny), to komponent tekstowy płynnie przeszedłby w obrazowy i odwrotnie, ustanawiając tym samym nowy rodzaj wzajemnej zależności wizualno-kinetycznej ${ }^{31}$.

30 Analizowana sekwencja tytułowa była jedną z najbardziej podziwianych w dorobku graficznym Bassa, a reklama filmu, która przywoływała to rozwiązanie designerskie, zdobyła wiele nagród. Bass wykonał również plakaty filmowe do: Zawrotu głowy, Północy - północnego zachodu i Psychozy. Współpraca grafika $\mathrm{z}$ reżyserem jest przedmiotem badawczym oddzielnego artykułu.

${ }^{31}$ Sugerowane przejścia obrazowo-ruchowe między różnosemiotycznymi znakami zrealizowane zostały w sekwencji tytułowej Psychozy, zaprojektowanej 

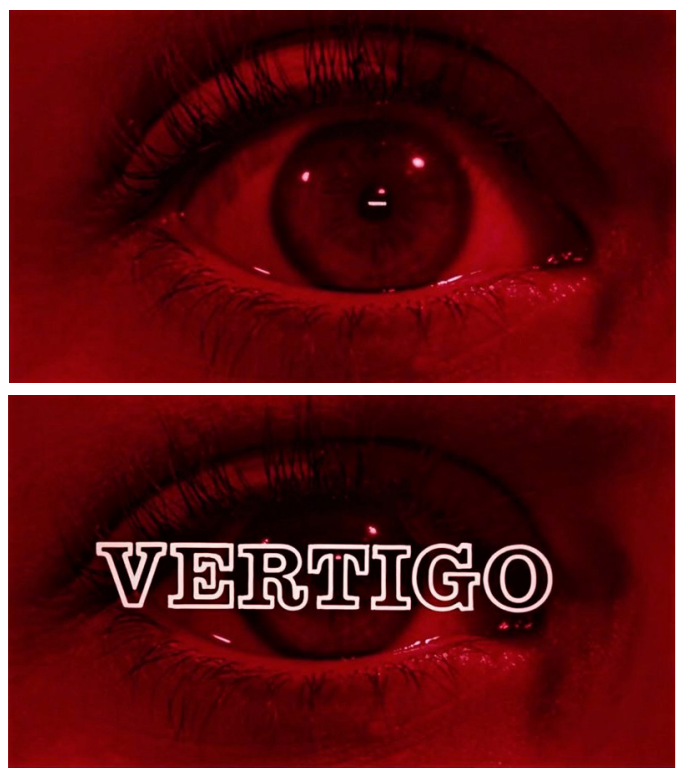

Il. 3 i 4. Kadry z filmu Zawrót głowy (1958)

To, że sekwencje tytułowe filmów są klasyfikowane jako graficzne, jest sprawą oczywistą. Dopiero integracja efektów designerskich z pozostałymi scenami filmu stanowi istotne novum. Rozwiązanie to zaproponowane zostało najprawdopodobniej przez Saula Bassa. Grafik-designer potraktował sekwencję tytułową Zawrotu głowy jak integralną część filmu, która przy użyciu muzyki, typografii i ruchomego obrazu może ustanowić nastrój i rejestr emocjonalny całości, a nawet „przypominać” zdarzenia poprzedzające akcję filmu ${ }^{32}$. Dlatego przywołane w czołówce filmu relacje różnosemiotyczne znajdują swą kontynuację w kolejnych kluczowych klatkach,

również przez Bassa. W tym przypadku zabieg graficzny był o wiele prostszy w realizacji, gdyż komponent obrazowy - czarne linie - zdecydowanie łatwiej przekształcić w zapis "psycho”: oba funkcjonują w układzie jednokierunkowym, wierszowym.

32 Zob. Saul Bass On His Approach To Designing Movie Title Sequences, 22.10.2015, „Art \& Science”, https://medium.com/art-science/saul-bass-on-his-approach-to-designing-movie-title-sequences-47fd537c457b [dostęp 10.02.2020]. 


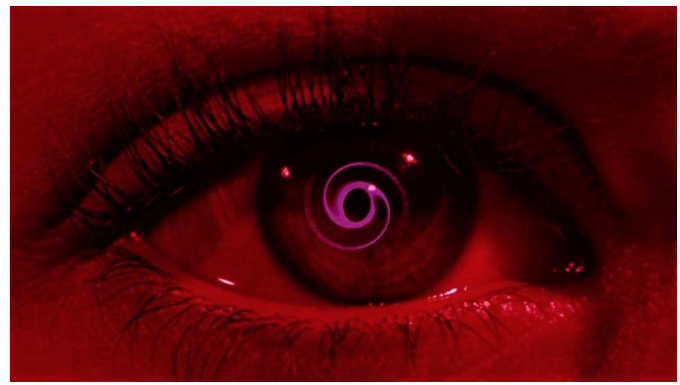

Il. 5. Kadr z filmu Zawrót głowy (1958)

ujęciach i scenach. Sekwencja tytułowa zbudowana jest dodatkowo poprzez kontrasty graficzne i syntetyczne oraz formy: spirale, koła, okręgi, elipsy. Te obracające się w różnych kierunkach, zwiększające się i malejące kształty mają również proweniencje designerskie ${ }^{33}$.

Przywołane formy symbolizują wrażenie zawrotu głowy, które towarzyszy tytułowemu bohaterowi filmu. Spirala wprowadza bowiem złudzenie ruchu kołowego, które polega na błędnej interpretacji obrazu przez mózg. Wrażenie dynamiki potęguje autentyczny ruch spirali. Animowane wirujące formy zmieniają gwałtownie swą skalę i swe kształty, w różnorodny sposób zapełniają przestrzeń: raz wypełniają ją, innym razem stanowią tylko jej mały komponent. Graficzne kształty pojawiają się w kolorach dopełniających, w odcieniach niebieskiego i żółtego, zielonego i czerwonego. Opisane zabiegi obrazowe pozwalają zbudować kontrast - podstawową zasadę przedstawienia graficznego ${ }^{34}$. Wykorzystuje on w sposób efektywny przeciwstawne wizualne wartości przedmiotów. Może zatem dotyczyć: skali - małe i duże; tonu - jasne i ciemne; barwy - zestawienia barw dopełniających się (czerwonej i zielonej, żółtej i niebieskiej); kształtu - formy okrągłe i formy ostre; kierunku - poziomy i pionowy; płaszczyzny - powierzchnie zabudowane i powierzchnie niezabudowane, otwarte i zamknięte; faktury gładki i chropowaty. Kontrast jest dodatkowo relacją względną, uzależnioną od cechy przedstawienia: jego wielkości, kształtu, barwy itd. Na przykład forma spirali wyda się bardziej zakręcona, gdy powiążemy ją z kątem ostrym, a kolor czerwony zrobi wrażenie bardziej intensywnego, gdy usytuujemy go

33 Pojawiają się wreszcie klasyczne lejtmotywy: oczy, usta.

34 R. Poulin, op. cit., s. 68. 
na zielonym tle. Kontrastowe relacje zostają ujawnione w takim połączeniu elementów, że wprowadzają zarówno efekt zróżnicowania, jak i jedności przedstawienia.

Opozycje obrazowe w filmie wprowadzone mogą być w obrębie: pojedynczego kadru, ujęcia, sceny i sekwencji. W przypadku najmniejszej statycznej jednostki filmu mamy do czynienia z kontrastem: barw dopełniających (zieleni i purpury), skali (mała postać i duża przestrzeń), faktury (śliski, atłasowy materiał sukni i wytłaczana, mięsista tapeta na ścianach). Zestawienie barw komplementarnych daje najsilniejszy kontrast wizualny, ponieważ kolory te mają największe różnice $\mathrm{w}$ zakresie długości fali, zatem leżą one po przeciwnych stronach koła barwnego i nie tworzą ze sobą form przejściowych (il. 6). Z poziomu percepcyjnego widz ulega dodatkowo zjawisku kontrastu równoczesnego. Towarzyszy mu złudzenie optyczne, które powoduje, że zieleń sukni wydaje się zdecydowanie bardziej nasycona, niż jest faktycznie, ponieważ została umieszczona na czerwono-purpurowym tle ściany.

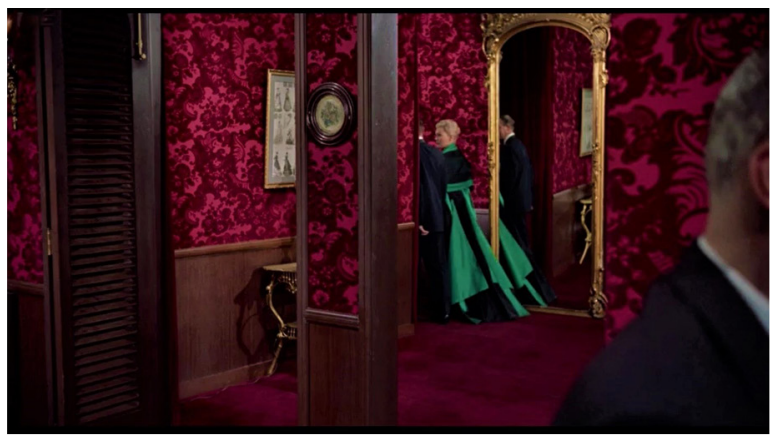

Il. 6. Kadr z filmu Zawrót głowy (1958)

Kontrast pojawia się następnie z poziomu ujęcia i może dotyczyć jednego lub kilku aspektów przedstawienia (il. 7 i 8). Obok zestawienia barw komplementarnych występuje kontrast wielkości (małe kwiaty i duże kwiaty), przestrzeni (zamkniętej i otwartej, niezabudowanej i zabudowanej, statycznej i dynamicznej). Za pośrednictwem animacji graficznych wzmocnione zostaje wrażenie kolistego ruchu, które towarzyszy zawrotom głowy. Dynamika przedstawienia jest również zmienna: raz wprowadza spowolnienie, innym razem przyspieszanie akcji. 

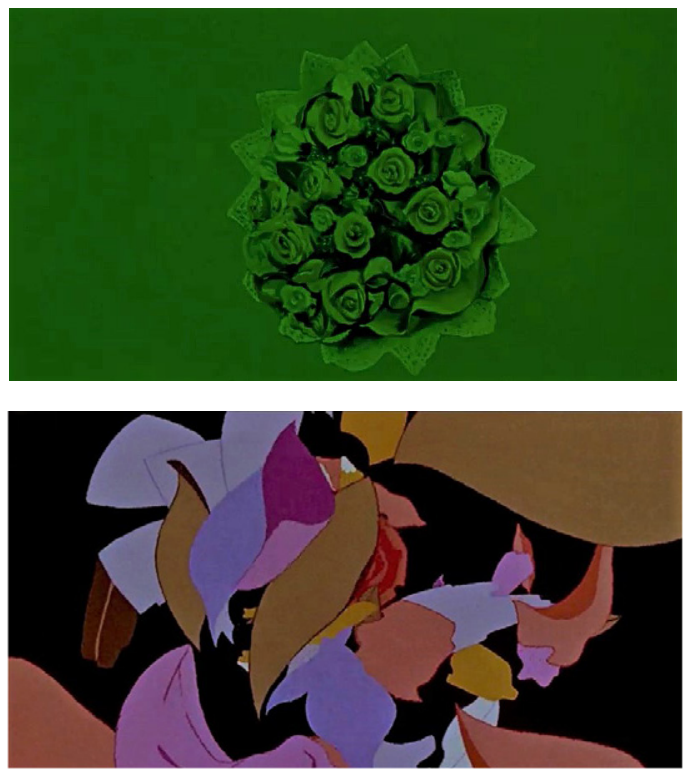

Il. 7 i 8. Kadry z filmu Zawrót głowy (1958)

Kontrast obecny jest również z poziomu sceny, czyli odcinka filmu, który wyróżnia się jednością miejsca i czasu akcji (il. 7-10), oraz z poziomu sekwencji, złożonej z kilku lub kilkunastu scen i odznaczającej się spójnością tematyczną lub dramaturgiczną. Drugą sytuację przywołują ilustracje 3-10. W prezentowanych sekwencjach filmowych pojawiają się analogiczne zestawienia barwne, gry wielkości i kształtów. Dodatkowo obecne są kontrasty faktur, wprowadzone przez „gładki” cień ludzkiego ciała i fakturalny gont dachu kościoła (il. 9 i 10).

Hitchcock wprowadzał z dużą konsekwencją zasadę kontrastu skali; $\mathrm{w}$ ten sposób zbudował większość planów filmowych w Zawrocie głowy. Sporadycznie przywoływał plan totalny, co było rzadkością i w czasach analizowanej produkcji, i w epoce kina klasycznego. Ten najszerszy z planów ukazywał szerokie przestrzenie krajobrazu, gdzie postać ludzka była ledwie widocznym detalem obrazu. Hitchcock odrzucił tę bezpieczną konwencję, która polegała na otwarciu planu widokiem typu proscenium, przejściu do planu pełnego, a następnie do zbliżenia. Reżyser kazał filmować w odwrotnej 

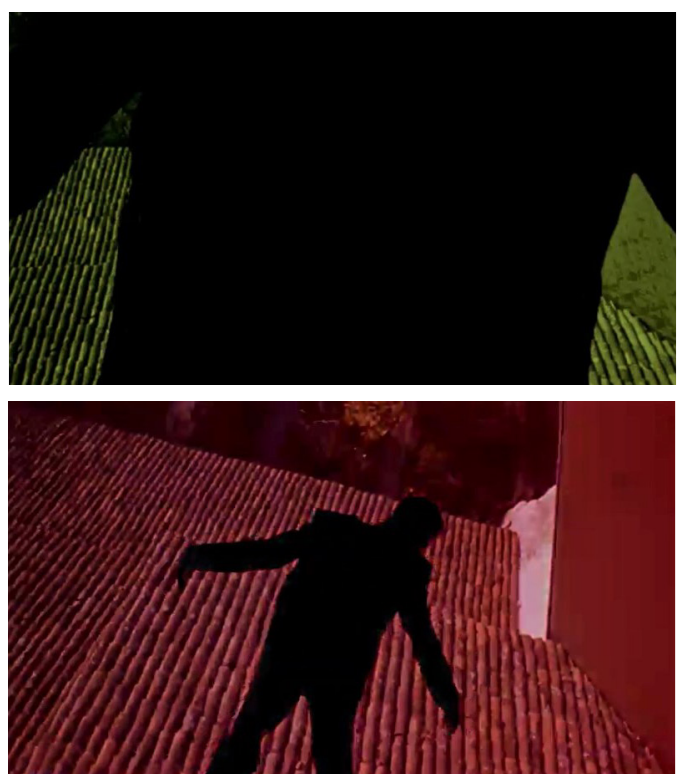

Il. 9 i 10. Kadry z filmu Zawrót głowy (1958)

kolejności. Zaczynał od dużego zbliżenia, np. ogromnej głowy, nawet przedstawienia detalu, np. oczu, ust, a kończył ujęciem pokrywającym. Detal, duże zbliżenie, w miejsce oczekiwanego planu totalnego lub ogólnego, dawał ulubiony efekt „trzęsienia ziemi”, wywoływał wstrząs lub podkreślał emocjonalne znaczenie. Szybkie przejście, nazywane „ruchem staccato”, między dużym zbliżeniem, zbliżeniem a planem ogólnym lub totalnym wprowadzało graficzną zasadę kontrastów. Reżyser, dopiero finiszując, proponował pełne ujęcie całej sceny. Zabieg ten ułatwiał zebranie ujęć zrealizowanych w bliższych planach i w detalach. Zaproponowana technika filmowania pozwalała również lepiej panować nad perspektywą, a reżyser musiał mieć wszystko pod kontrolą ${ }^{35}$.

35 Fragment przywołany na podstawie: P. McGilligan, op. cit., s. 45. 


\section{KONTRAST WIZUALNY A SUSPENS}

Suspens definiowany jest w literaturze przedmiotu jako wstrzymanie biegu akcji w celu wzmocnienia napięcia lub zaskoczenia widza nieprzewidywanym zwrotem zdarzeń. Tymczasem Hitchcock, określany mianem „mistrza suspensu”, rozumie analizowany chwyt jako przede wszystkim sposób podtrzymania uwagi i zbudowania napięcia odbiorczego i pomija element zaskoczenia. Reżyser - jeszcze jako grafik - dobrze poznał swoich odbiorców, ich oczekiwania, pragnienia i potrzeby ${ }^{36}$. Wielokrotnie podkreślał, że „suspens wymaga, żeby publiczność była doskonale poinformowana o wszystkich istotnych elementach" ${ }^{37}$. Dlatego też reżyser spowalniał akcję poprzez pokazywanie widzowi tego, czego nie wiedzą jeszcze bohaterowie filmu, np. w Zawrocie głowy obserwujemy Judy piszącą list do Scottie'go lub przypominającą sobie moment zbrodni. Informacja okazywała się najodpowiedniejszym środkiem do długotrwałego podtrzymywania uwagi widza, angażowała go w przedstawienie, czyniła go nawet „podglądaczem” zdarzeń filmowych.

We wspomnianej rozmowie $\mathrm{z}$ francuskim reżyserem Hitchcock podkreślił, że trzeba stale „wyjaśniać”, a Truffaut dodał: „i upraszczać”. Wtedy reżyser Zawrotu głowy, na potwierdzenie powyższej tezy, powiedział: „Ludzie, którzy nie umieją "upraszczać«, nie mogą kontrolować przydzielonego im czasu, niepokoją się, ale »abstrakcyjnie«, i ten ich pusty niepokój uniemożliwia im koncentrację na konkretnych zajęciach, tak jak zły konferansjer traci głowę, kiedy za bardzo skupia się na sobie samym"38. Uproszczenie przekazu następuje poprzez myślenie kategorią kontrastu - np. danej własności jest dużo lub mało - i na tej podstawie następuje wyłonienie cech istotnych przedmiotu, z pominięciem mniej ważnych. Wrażenie to potęguje dodatkowo przedstawienie kontrastowe przedmiotu, czyli ujęcie go np.

36 Badacze reklamy wielokrotnie sugerowali, że wiele $\mathrm{z}$ tych scen filmowych doskonale przekłada się na ich komercyjne wykorzystanie. Nawet zarzucano Hitchcockowi, że myślał w „sposób efekciarski”, czytaj: „graficzny”. Ackroyd cytował reżysera: „Zawsze byłem w stanie przewidzieć relację publiczności, ale tym razem [w przypadku Psychozy - A.S.] zupełnie mi się nie udało"; P. Ackroyd, op. cit., s. 248.

${ }^{37}$ F. Truffaut, op. cit., s. 66.

38 Ibidem, s. 84. 
w dwóch różnych wielkościach lub przeciwstawnych barwach. Z punktu widzenia odbioru opisane zjawisko kontrastu pozwala uwidocznić cechy konstytutywne przedmiotu, z pominięciem drugoplanowych, i wskazać kluczowe zależności między przedstawieniami.

Okazuje się, że zawieszenie biegu akcji następuje przez gromadzenie informacji i jej syntetyzowanie, które dokonuje się przy udziale kontrastów: poznawczego i obrazowego. Podczas zawieszenia zdarzeń widz albo jest ciekawy ich dalszego rozwoju, albo przewiduje to, co może się wydarzyć, lecz nie wie, jak to się stanie. Odbiorca odczuwa wtedy pewien rodzaj napięcia. Wydaje się, że ów niepokój może również wynikać z kontrastu poznawczego: posiadania wiedzy (przez oglądającego) i jej braku (w przypadku postaci filmowej). Z pewnością natomiast źródłem owego napięcia percepcyjnego, potem poznawczego, jest analizowany kontrast obrazowy. Musi on być odpowiednio silny, by stał się faktycznie skuteczny. Wtedy obraz staje się (1) wizualnie atrakcyjny, przez to (2) immersyjny i dlatego w efekcie (3) perswazyjny. Przekaz ulega intensyfikacji, wzmocnieniu, staje się bardziej bezpośredni, sugestywny, magiczny, irrealny. Dlatego silniej ekscytuje widza i przyciąga na dłużej jego wzrok, może nawet powodować zawroty głowy. Nagłe zbliżenie twarzy i jej gwałtowane oddalenie, gra barw dopełniających, faktur i przestrzeni, wszystkie te zjawiska wywołują wstrząs odbiorczy, są one jak „głośna nuta” w muzyce. W tym miejscu pojawia się kolejny kontrast: między „narracyjnym” nagromadzeniem elementów racjonalnych (informacyjno-syntetycznych) i elementów irracjonalnych (wizualnych, nierealistycznych). Obie własności są ze sobą sprzęgnięte. Zatem i wiedza (dotycząca szczegółów akcji), i widzenie (skontrastowanych wielkości, kształtów, barw i faktur przedmiotów) staje się źródłem napięcia, które trwa aż do odkrycia tego, co się wydarzyło i dlaczego. Rozwiązanie filmu następuje dopiero na 30 minut przed jego końcem.

Reżyser okazał się dobrym psychologiem poznawczym, suspens odpowiada bowiem bardzo dobrze oczekiwaniom i potrzebom widza, nawet „funduje” mu specyficzny rodzaj przyjemności (związany z pojęciem rozgrywki). Wstrzymanie akcji - rozpatrywane z poziomu psychologicznego - składa się z dwóch skontrastowanych stanów: strachu i nadziei, które wywołują poznawczą niepewność. Strach rozumiany jest jako uczucie niezadowolenia z perspektywy niepożądanego rozwiązania, a nadzieja - jako uczucie przyjemności z perspektywy pożądanego zdarzenia. Czyli i strach, i nadzieja 
zależne są od pożądania. Oba kontrastowe stany psychiczne wzmagane są przez kontrasty obrazowe: skali, tonu, barwy, faktury (również dysonanse dźwiękowe i kinetyczne). Poziomy emocjonalny i percepcyjny zależą od pożądania i przyszłego, nieokreślonego jeszcze rozwiązania zdarzeń: w przypadku stanu psychicznego - rozwikłania zbrodni, w przypadku stanu wizualnego - rozwikłania znaczeń ${ }^{39}$. Obie emocje „odnoszą się” do analogicznych stanów: pożądania i wyniku, ale „zachowują się” przeciwstawnie. Również dysonanse, jak powiedzieliśmy wyżej, budują jedność wizualną, zarazem kontrastując elementy przedstawienia. Przykładem tej zależności jest np. zjawisko powidoku, w którym ten sam przedmiot postrzegany jest w dwóch kontrastowych barwach.

Suspens wprowadzony jest w celu zbudowania napięcia, a ono z kolei najczęściej związane jest $\mathrm{z}$ niepewnością. Zatem największe napięcie pojawia się, gdy wynik (pożądany lub niepożądany) rozwiązania jest niepewny. Również kontrast, np. barwny, powoduje, że wzrok, nie mogąc sfokusować się na przedstawieniu, skacze kaskadowo, błądzi, jest w stanie rozedrgania, niepewności percepcyjnej ${ }^{40}$. Można zatem hipotetycznie założyć, że nie może być napięcia, jeśli nie ma niepewności poznawczej.

W tym miejscu pojawia się zjawisko klasyfikowane jako „paradoks suspensu": suspens wymaga niepewności, tymczasem znajomość przebiegu zdarzeń przez widza wyklucza niepewność, a mimo wszystko oglądający reaguje napięciem na niektóre historie, nawet mając wiedzę o ich

39 Powyższe wnioski potwierdzają obserwacje psychologów, którzy zauważają, że strach wzmaga się w momencie, gdy wzrasta stopień zagrożenia lub prawdopodobieństwo rozwiązania, natomiast nadzieja odwrotnie - maleje wraz ze wzrostem zagrożenia i prawdopodobieństwem rozwiązania.

${ }^{40} \mathrm{Z}$ analogiczną sytuacją spotykamy się w przypadku kontrastu barw dopełniających lub bieli i czerni. W drugim przypadku wzrok błądzi po szachownicy, nie mogąc się zatrzymać, tym samym komórki neuronalne są non stop pobudzane i zmuszane do działania, szukania rozwiązania. Efekt ten wykorzystany został z mistrzowska precyzją np. w Psychozie, stworzonej w tonacji czarno-białej, ponieważ kolor rozpraszałby uwagę widzów, a krew cieknąca odpływem prysznicowym byłaby odpychająca. 
zakończeniu ${ }^{41}$. Gdy kolejny raz oglądamy film Zawrót głowy, napięcie jest nieco mniejsze, ale istnieje nadal, mimo że znamy już rozwiązanie. Zjawisko to można tłumaczyć w następujący sposób: informacja, wprowadzająca zawieszenie akcji, docierała do nas w formie komunikacji obrazowej, czyli zmiennie konstelacyjnych układów elementów, a nie komunikacji językowej, czyli następstwa przyczynowo-skutkowego, które buduje spójną narrację. Mamy pewność - wiedzę tylko na temat wyniku końcowego, czyli rozwiązania akcji. Nie jesteśmy jednak przekonani, czy „podglądając” zdarzenia filmowe, wyłapaliśmy wszystkie szczegóły i powiązania między nimi. I ta niepewność powoduje, że z napięciem (nieco mniejszym niż za pierwszym razem) oglądamy kolejny raz film, porównujemy go z zakodowanymi obrazami lub poszukujemy obrazowych szczegółów ${ }^{42}$.

Dodatkowo, jak ustalono wyżej, owo „racjonalne wiedzieć” może być mocno zsyntetyzowane i pozostawać w złożonej relacji z „irracjonalnym widzieć”. Sam reżyser proporcje między tymi komponentami widział w następujący sposób: „W ogóle nie jestem realistą, pociąga mnie fantastyka. »Widzę rzeczy większe od życia «" $"$. Magia ciągłobarwnego obrazu filmowego jest zatem bardzo istotna i nie zanika ona po jego obejrzeniu, przeciwnie pozostawia na trwałe swój mglisty ślad w „mentalnym zasobie obrazów”. Dlatego chcemy ponownie obejrzeć obraz i przeżyć towarzyszące mu emocje.

Zaproponowane wyżej tłumaczenia zjawiska „paradoksu suspensu” wydają się słuszne w kontekście stwierdzenia, że Hitchcock myślał swobodnie obrazami, nie troszczył się specjalnie o ich powiązanie, nawet miał problem z ich połączeniem w jedną spójną narrację; bardziej interesował go szczegół,

${ }^{41}$ Zob. A. Smuts, The Paradox of Suspense, 6.07.2009, „Stanford Encyclopedia of Philosophy", https://plato.stanford.edu/entries/paradox-suspense/ [dostęp 10.02.2010].

${ }^{42}$ Idąc krok dalej: kontrast jest nie tylko sposobem na zbudowanie i podtrzymanie uwagi oraz napięcia odbiorczego. On sam stanowi źródło informacji. Może ukierunkować uwagę, stworzyć hierarchię, podkreślić elementy determinujące ważność, zbudować tym samym semantykę przedstawienia. Na dowód tego suspens, podobnie jak zjawisko kontrastu, bywa definiowany jako „trudny rebus”; oba czytane-oglądane są konstelacyjnie: z góry na dół, od lewej do prawej i po skosie.

43 Por. P. Ackroyd, op. cit., s. 88. 
pojedyncza scena niż całkowita opowieść ${ }^{44}$. Działał tak, jakby wielokrotnie filtrował obraz, by go maksymalnie oczyścić ze zbędnych informacji wizualnych. A ten sposób myślenia bliski jest wnioskowaniu obrazowemu typu graficznego, gdzie „punktem wyjścia jest nie zawartość, a pojemnik” ${ }^{\prime 5}$. Film był dla Hitchcocka rodzajem naczynia, które trzeba „naładować emocją", „wypełnić”, z którego usunąć należy „dziury dramaturgiczne” i „plamy nudy”46. Reżyser lubił „mocne, kontrastowe” sytuacje, ponieważ łatwiej je przedstawić obrazowo. Nie prezentował zwykłych ludzkich spraw, ale problemy, dylematy moralne, bo one wydawały mu się bardziej ciekawe graficznie. Postaci również rysował/projektował w sposób kontrastowy, kilkoma liniami, opozycyjnymi wielkościami i barwami. Zjawisko to jest dobrze widoczne w przypadku kreacji głównej postaci kobiecej. W „wersji Madeleine" to bogata, wykształcona, dystyngowana, tajemnicza dama, o delikatnym makijażu, subtelnie zaznaczonym konturze oczu, starannie upiętych blond włosach, ubrana w klasyczny szary kostium. Judy to z kolei biedna, słabo wyedukowana, pretensjonalna sprzedawczyni o krzykliwym makijażu i kasztanowych włosach. Podwójny portret tej samej osoby jest zatem mocno uproszczony, bo dla „pogłębienia postaci potrzeba zbyt wielu słów"47. A podwójna kreacja tytułowej bohaterki, jako Madeleine i Judy, jest chyba najlepszym dowodem i przejawem kontrastowego poznania świata ${ }^{48}$.

$* * *$

Wszystkie przywołane wyżej argumenty i cytaty świadczą niezbicie o tym, że filmy Hitchcocka trudno analizować i interpretować w porządku linearnym,

${ }^{44}$ Ibidem, s. 76, 161.

45 F. Truffaut, op. cit., s. 300.

46 Ibidem, s. 17.

47 Ibidem.

48 Kontrast graficzny podbity jest kontrastem muzycznym, zrealizowanym przez kompozycje Bernarda Herrmanna. Również losy filmu można widzieć w kategoriach kontrastu odbiorczego: początkowo, w momencie premiery w 1958 roku, realizacja wzbudziła skrajnie negatywne emocje, a dzisiaj film klasyfikowany jest, obok Psychozy i Ptaków, jako jeden z najcenniejszych w dorobku Hitchcocka. W 2012 roku w ogłaszanej co dziesięć lat ankiecie „Sight and Sound” uznany został nawet za najlepszy film w dziejach. 
przyczynowo-skutkowym. Jego realizacje bliskie są grafice, a sam reżyser ustawiał je w porządku muzycznym lub malarskim, nie literackim, gdyż nie ufał literaturze ${ }^{49}$. Dlatego wysoko cenił filmy nieme. W wywiadzie mówił: „Filmy nieme to najczystsza forma kina” ${ }^{50}$, brakowało im tylko naturalnego dźwięku. Niestety, wraz z nadejściem słowa mówionego powróciła przeciętność kina, znana $\mathrm{z}$ jego początków, ale potem wyeliminowana. Dlatego wydaje się, że „słuchanie” filmów, a potem ich interpretacyjne „czytanie” może okazać się procedurą niewystarczającą, niepełną ${ }^{51}$. Również analizowanie suspensu jako sposobu budowania napięcia poprzez odwołanie do kategorii „narracji” (wzorowanej na podstawowych związkach przyczynowo-skutkowych, znanych z rozwiązań literackich) może budzić pewien opór badawczy ${ }^{52}$. Zdaniem Hitchcocka kinowy sposób opowiedzenia historii

49 Reżyser zarzucał nawet krytykom, że „mają tendencję to przeceniania literackiej wartości filmu, a niedoceniania - filmowej”; F. Truffaut, op. cit., s. 63.

50 Reżyser mówił: „Kiedy pisze się scenariusz, niezbędne jest wyraźne oddzielenie elementów dialogowych od elementów wizualnych; potem zaś zawsze, kiedy to tylko możliwe, trzeba wybierać elementy wizualne; ibidem, s. 57-58.

${ }^{51}$ Sam Hitchcock „prywatnie nabijał się z dywagacji nad symboliką jego dzieł, bo nierzadko być może na siłę dorabiano w ten sposób interpretację do tego, co było przypadkowe i niezamierzone"; P. Ackroyd, op. cit., s. 129. Dlatego dla większej pewności badawczej interpretacja powinna być poprzedzona wnikliwym obejrzeniem kadrów filmowych i ich analizą pod kątem obrazowych środków wyrazu artystycznego, np. kontrastu. I dopiero na tej podstawie można komentować Zawrót głowy jako grę egzystencjalną między tym, co realne, i tym, co nierealne, między światem żywych (przedstawianych w ciepłych, czerwono-purpurowych, odcieniach) i światem zmarłych (sugerowanych zielonymi barwami). Kontrast barwy i skali pozwalał wiązać z sobą światy ontologicznie różne. Zieleń przeplatała się z czerwienią na każdym poziomie organizacji filmu: w kolejnych sekwencjach, scenach, ujęciach i kadrach. Kontrast barwny dotyczył nawet jednego wizualnego komponentu: zielony neon hotelu sugestywnie oświetlał żywą twarz Judy, czyniąc z niej w tym momencie zmarłą Madeleine.

${ }^{52}$ Pomimo pojawiających się wyżej zastrzeżeń niektóre filmy Hitchcocka, np. Pótnoc, pótnocny zachód, Starsza Pani znika, Trema, traktowane są (zresztą niekonsekwentnie) jako przykład narracji klasycznej: opartej na stałych wzorcach fabularnych, czyli pozbawionej eksperymentów i przezroczystej formalnie; zob. np. J. Ostaszewski, Historia narracji filmowej, Kraków 2018, s. 111-112. 
polega bowiem na przenikaniu się obrazów, na nielinearnym przepływie ujęć i scen, a technika filmowa pozwala na jeszcze bardziej swobodne wymyślanie obrazów i powiązań między nimi ${ }^{53}$. Dlatego reżyser widział potrzebę ustawiania obrazów na ekranie w taki sposób, by nie były one skrępowane realną rzeczywistością i następstwem przyczynowo-skutkowym. I tak należałoby rozumieć „obrazowość” filmów Hitchcocka, a kontrast graficzny stanowi narzędzie komunikacyjne, które pozwala wyodrębnić kontekstowo informacje kluczowe.

\section{Bibliografia}

Peter Ackroyd, Alfred Hitchcock, tłum. J. Łoziński, Zysk i S-ka, Poznań 2015.

Dan Auiler, Vertigo. The Making of a Hitchcock Classic, St. Martin's Griffin, New York 1998.

Charles Barr, Vertigo, British Film Institute Publishing, London 2002.

Boileau-Narcejac, Zawrót głowy, tłum. F. Welczer, Czytelnik, Warszawa 1968.

Piotr Francuz, Imagia. W kierunku neurokognitywnej teorii obrazu, Wydawnictwo KUL, Lublin 2013.

Krzysztof Loska, Hitchcock - autor wśród gatunków, Rabid, Kraków 2002.

Patrick McGilligan, Alfred Hitchcock. Życie w ciemności i petnym świetle, tłum. J. Matys [et al.], „Twój Styl”, Warszawa 2005.

Jacek Ostaszewski, Historia narracji filmowej, TAiWPN Universitas, Kraków 2018. Marek Ples, Krzywe Lissajous - piękno drgań, „Młody Technik” 2015, nr 6.

Richard Poulin, Jezyk projektowania graficznego. Ilustrowany podręcznik podstawowych zasad projektowania graficznego, TMC, Warszawa 2011.

Janusz Skwara, Hitchcock, Wydawnictwa Filmowe i Artystyczne, Warszawa 1974. Donald Spoto, Alfred Hitchcock, tłum. J.S. Zaus, Alfa, Warszawa 2000.

François Truffaut, Hitchcock / Truffaut, współpraca H. Scott, tłum., oprac. i posł.

T. Lubelski, „Świat Literacki”, Izabelin 2005.

53 Tezę te potwierdzają również jego fascynacje malarskie. Hitchcock kupował dzieła malarzy-grafików Raoula Dufy'ego, Maurice’a Utrilla, Waltera Sickerta i Paula Klee. Córka Patrycja podkreślała, że ojciec cenił przede wszystkim sztukę niefiguratywną, jeśli była przyjemnym doznaniem wizualnym. „Natomiast kompletnie nie interesowało go malarstwo symboliczne, ukryte znaczenia”; P. Ackroyd, op. cit., s. 24. 
Slavoj Žižek, Lacrimae rerum. Kieślowski, Hitchcock, Tarkowski, Lynch, tłum. G. Jankowicz [et al.], przedm. K. Mikurda, Wydawnictwo Krytyki Politycznej, Warszawa 2011.

\section{Źródła internetowe}

Tom McCormack, Did 'Vertigo' Introduce Computer Graphics to Cinema?, 9.05.2013, Rhizome, https://rhizome.org/editorial/2013/may/9/did-vertigo -introduce-computer-graphics-cinema/.

Saul Bass On His Approach To Designing Movie Title Sequences, 22.10.2015, Art \& Science, https://medium.com/art-science/saul-bass-on-his-approach-to-designing-movie-title-sequences-47fd537c457b.

Aaron Smuts, The Paradox of Suspense, 6.07.2009, Stanford Encyclopedia of Philosophy, https://plato.stanford.edu/entries/paradox-suspense/.

The Hitchcock Zone, https://the.hitchcock.zone/welcome/.

Geoff Todd, Drawings for a Master: Storyboards From The Films of Alfred Hitchcock, 25.11.2015, Film School Rejects, https://filmschoolrejects.com/gallery-drawings-for-a-master-storyboards-from-the-films-of-alfred-hitchcock-c0bc20 $77 \mathrm{c} 03 /$.

Who Directed the Shower Scene in PSYCHO? [wideo], https://vimeo.com/86791716.

\section{Źródła ilustracji}

1-2. https://vimeo.com/142989166 [dostęp 10.02.2010].

3-10. Zawrót głowy (Vertigo), reż. Alfred Hitchcock, USA 1958.

\section{Analysis of the Graphic Principle of Contrast in Alfred Hitchcock's Vertigo}

The film was a purely visual event for Hitchcock. That is why the director enjoyed using the means of pictorial expression, such as contrasts in: scale small and large; tone - light and dark, colors - complementary colors (red and green, yellow and blue), shape - round and sharp forms, direction horizontal and vertical; planes - built-up areas and undeveloped, open and closed areas; textures - smooth and rough. Contrasts appeared within: single frame, shot, scene and sequence. The suggested graphic oppositions contributed to the phenomenon of suspense that Hitchcock was a master of. In this case, the suspension of the course of action was required through 
the collection of information and its synthesis, which was carried out with the use of visual contrasts, which led to cognitive oppositions. During the suspension of the course of events, the viewer was either curious about the further development of events or anticipated what might happen, but did not know how it would happen. The viewer then felt a certain kind of tension. The analyzed image contrast was the source of this perceptual and then cognitive tension. It had to be strong enough to be actually effective. Then the image became visually attractive (1), thus immersive (2) and therefore persuasive (3). The sudden close-up of the face and its sudden distance away, the play of complementary colors, textures and space, all these phenomena caused the anticipated perception shock. Suspension - considered from the psychological level - also consisted of two contrasting states: fear and hope, which induced cognitive uncertainty. Both opposing mental states were built, among others, through the contrasts of images: scale, tone, color, texture (also sonic and kinetic dissonances).

Keywords: graphic rules, visual contrast, drawing, technique, suspense 